\title{
Synthesis of trypanocidal tetrahydrofuran lignans
}

\author{
Ken-ichi Nihei, ${ }^{a}$ Katsuhiro Konno, ${ }^{b}$ Lilian Sibele Campos Bernardes, ${ }^{c}$ \\ Norberto Peporine Lopes, ${ }^{c}$ Sergio Albuquerque, ${ }^{c}$ Ivone de Carvalho, ${ }^{c}$ \\ Mônica Talarico Pupo, ${ }^{\mathrm{c}}$ Roberto Carlos Campos Martins, ${ }^{a}$ and Massuo Jorge Kato ${ }^{a}$ \\ ${ }^{a}$ Instituto de Química, Universidade de São Paulo, C.P. 26077, CEP 05599-970, \\ São Paulo, SP - Brazil, ${ }^{b}$ Instituto Butantan, ${ }^{c}$ Faculdade de Ciências Farmacêuticas de Ribeirão \\ Preto, Universidade de São Paulo \\ E-mail: majokato@iq.usp.br
}

\section{In honor of Professor Otto R. Gottlieb}

(received 30 Jan 04; accepted 17 Aug 04; published on the web 27 Aug 04)

\begin{abstract}
Several tetra-substituted 2,5-dihydrofuran lignans have been prepared using a sequential Michael addition-carbocyclization with palladium as the catalyst. The synthetic compounds were evaluated against trypomastigote forms of Trypanossoma cruzi and the higher activity for diastereoisomeric compounds could be correlated to the trans configuration of the aromatic rings. The highest activity was observed for compound $\mathbf{1 4 b}$ in which $\mathrm{IC}_{50}$ was $1.5 \mu \mathrm{M}$.
\end{abstract}

Keywords: Tetrahydrofuran lignans, Chagas disease, trypanocidal

\section{Introduction}

Chagas disease is an important tropical disease caused by the protozoan Trypanosoma cruzi which has the hematophagous reduviid bug Rhodnius prolixus (Hemiptera) as major parasite vector. It is endemic to 21 countries with 16-18 million already infected in Latin America and with approximately 100 million of the people living at risk. ${ }^{1-3}$ Approximately $30-40 \%$ of the patients are affected by irreversible heart and gastrointestinal tract lesions. ${ }^{4,5}$ Thus, such disease has caused approximately 3 million disabilities each year. Therefore, it represents a very serious public health and economic problem in these countries.

The search for solutions has been attempted in several different directions. In particular, an important approach has been addressed to the development of new drugs, vaccine therapy, besides the controlling of the specific vector. ${ }^{1-3}$ To date there have been only two trypanocidal drugs, Nifurtimox (4-[(5-nitrofurfurylidene)amino]-3-(methylthio)morpholine 1,1-dioxide) and benznidazole (N-benzyl-2-nitro-1-imidazoleacetamide). The daily administration of 
benznidazole to the early chronic patients for two months has diminished the risk of developing cardiomyopathy. ${ }^{1}$ However, the side effect to overdose for a long term of the treatment and the emergence of the drug resistant strain has been the major challenges. ${ }^{6-8}$

Due to the increasing influx of people into urban area and the transfusion of contaminated blood, the disease characteristics has changed from endemic to epidemic. ${ }^{1,9}$ Between 1960 and 1989, the prevalence of infected blood in blood banks in selected cities of South America ranged from 1.7 \% in São Paulo, Brazil to 53.0 \% in Santa Cruz, Bolivia, a percentage far higher than that observed for hepatitis or HIV infection. In this regard, an approach to eliminate the parasite in blood involve the chemoprophylactic agent, crystal violet (N-\{4-bis[[4-(dimethylamino)phenyl]methylene]-2,5-cyclohexadien-1-ylidene\}-N-methylammonium chloride), a dye discovered to be effective many years ago. ${ }^{10}$ Nevertheless, such treatment has not been well accepted by patients due to the bluish colour it confers to the blood.

A number of investigations dealing with effective trypanocidals described the isolation of diterpene, ${ }^{11}$ naphtoquinones, ${ }^{12}$ and lignans ${ }^{13-15}$ as active compounds. Our research group started with the investigation of natural products as a potential source of trypanocidal drugs since $1998^{13}$ when the lignans (-)-grandisin (1) and (+)-veraguensin (2) were discovered as the most active natural products against trypomatigote forms of Trypanosoma cruzi. These structurally simple lignans were formerly isolated from twigs of Virola surinamensis, a common woody species from Amazon Forest. Since both compounds showed potency about forty times higher than crystal violet (Figure 1), we envisaged further investigations of synthetic analogs in order to better understand the structure-activity relationship.

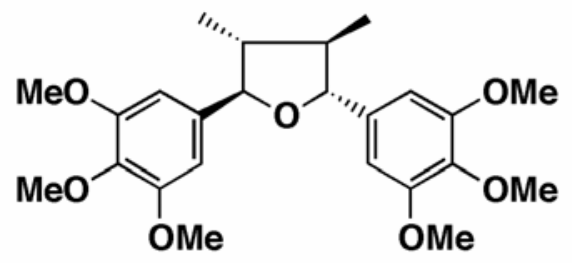

$(-)$-grandisin (1)

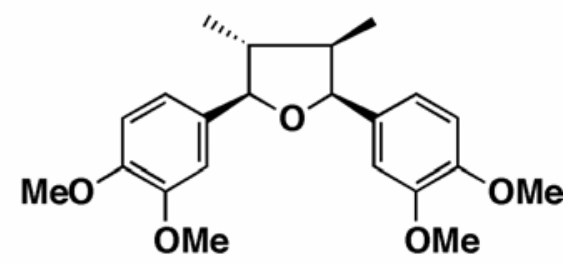

(+)-veraguensin (2)

Figure 1

A drug candidate with simple structure would be desirable, because it would allow the access of a large number of derivatives and then studies involving structure-activity relationship would be carried out.

Such considerations prompted us to synthesize several derivatives of $\mathbf{1}$ and $\mathbf{2}$, via a short and simple convergent route. Our general strategy was based on the construction of a tetrahydrofuran (THF) ring by using sequential Michael addition-carbocyclization reaction with palladium catalyst. $^{16}$ We report herein, the synthesis of several THF lignan derivatives and their trypanocidal activity. 


\section{Results and Discussion}

In the strategic analysis to synthesize THF lignans and its derivatives, methylenetetrahydrofuran 3 was chosen as a viable intermediate for the easy introduction of several functional groups at the THF ring (Scheme 1). The key step in the proposed sequence, a Michael additioncarbocyclization, would provide 3 from 1.5 equivalent (eq) of propargyl alcohol 4 as a donor and arylidenemalonate $\mathbf{5}$ with vicinal electron withdrawing groups as a acceptor (EWG) by using substoichiometric amounts of palladium reagent and base. ${ }^{16}$ Moreover, this reaction could be carried out in hindered substrates at the aromatic moieties such as $\mathbf{4}$ and $\mathbf{5}$.

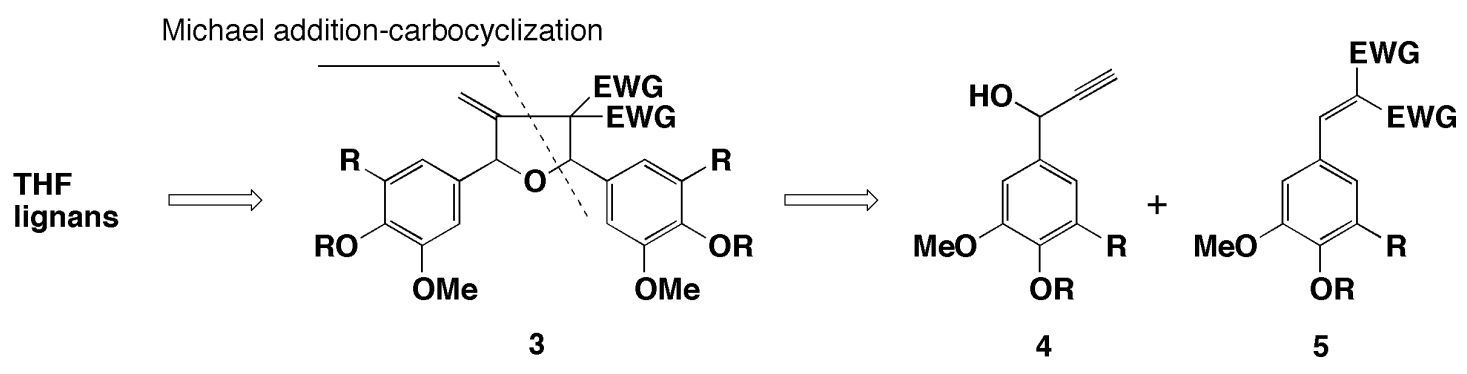

\section{Scheme 1}

The first objective in the synthesis was the development of workable synthesis of propargyl alcohol 7 and arylidenemalonate 10 (Scheme 2). The 3,4,5- trimethoxybenzaldehyde (6) was converted to 7 via addition of ethynylmagnesium bromide in high yield. On the other hand, preparation of 10 started with syringaldehyde (8), which was converted to the corresponding benzyl ether 9 using $\mathrm{K}_{2} \mathrm{CO}_{3}$ in dimethylformamide (DMF). In this step, the typical reaction conditions using $\mathrm{NaH}$ in THF or DMF, and $\mathrm{K}_{2} \mathrm{CO}_{3}$ in acetone, were conducted to the formation of a complex mixture. Knoevenagel reaction with diethyl malonate and $\mathbf{9}$ by using catalytic amount of pyrrolidinium acetate gave rise to $\mathbf{1 0}$ in high yield but without decarboxylation. ${ }^{17,18}$

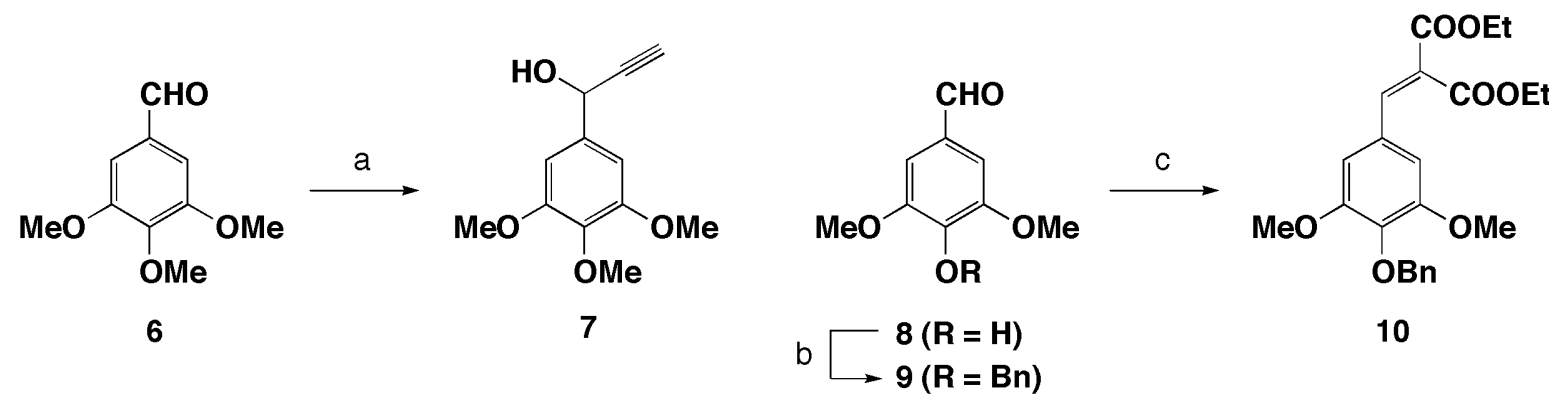

Reagens and conditions: (a) $\mathrm{HCCHMgBr}$, THF, $0{ }^{\circ} \mathrm{C}, 83 \%$; (b) $\mathrm{BnBr}, \mathrm{K}_{2} \mathrm{CO}_{3}, 75^{\circ} \mathrm{C}, 97 \%$; (c) diethylmalonate, $\mathrm{AcOH}$, pyrrolidine, toluene, $\Delta, 80 \%$

Scheme 2 
The formation of the methylenetetrahydrofuran $\mathbf{1 1}$ from $\mathbf{7}$ and $\mathbf{1 0}$ was accomplished through a sequential Michael addition-carbocyclization protocol using improved Balme's palladiummediated approach (Figure 2). ${ }^{16}$ Treatment of 7 with catalytic amount of n-butyl lithium (n$\mathrm{BuLi}$ ) generated the corresponding alkoxide in few minutes. After sequential addition of catalytic amount of $\mathrm{Pd}(\mathrm{AcOH})_{2}$, triphenylphosphine (TPP), and 10, the substrates were smoothly converted to a diastereomeric mixture $\mathbf{1 1 a}$ and $\mathbf{1 1 b}$ after $12 \mathrm{~h}$ in excellent yield (entry 2). The low diastereoselectivity was interesting in this case since many types of compounds could be generated. This 'one pot reaction' to couple tertiary alcohol and arylidenemalonate in high yield could not be promoted by adding over 0.1 eq of $n-B u L i$, as shown in the original reference (entry 3 and 4$)^{16}$ but using a reaction time of $12 \mathrm{hr}$ (entry 1). These results paved a way to the possibility of coupling between several hindered Michael acceptor and donor substituted at the aromatic moiety. Since the mixture of diastereomeric compounds was quite difficult to separate by silica gel column, the following reaction was then performed with the diastereomeric mixture.

At the next step, although several conditions mentioned in Krapcho's report were tried, simply mono-decarboethoxylated THF compound from 11 could be obtained only in low yield. ${ }^{24}$ For example, the treatment of $\mathrm{KCN}$ in dimethylsulfoxide (DMSO) under $150{ }^{\circ} \mathrm{C}$ was obtained to corresponding mono-decarboethoxylated furan in $26 \%$ yield. The desired compound could be one of the precursors to synthesize THF lignan derivatives, but due to the low yield, the optimization of the next reaction step was further investigated. Treatment of 11 with an alkaline aqueous solution followed by acidification provided monocarboxylic acid 12 via sequential reactions of hydrolysis of ester, decarboxylation, and isomerization of olefin in high yield (Scheme 3). Since it was difficult to separate the mixture of each diastereomer by silica gel chromatography, the mixture $\mathbf{1 2 a} / \mathbf{1 2 b}$ was treated with excess of $\mathrm{LiAlH}_{4}$. However, complete transformation to the corresponding allyl alcohol 14 did not occur. Accordingly, 12a/12b was treated with MeI and 1,8-diazabicyclo[5.4.0] undec-7-ene (DBU) to yield methyl ester 13a/13b $\mathbf{b}^{25}$, which was then converted to $\mathbf{1 4 a / 1 4 b}$ by using $\mathrm{LiAlH}_{4}$ in high yield without 1,4-reduction products. The allyl alcohols 14a and 14b were easily separated using silica gel column chromatography. 


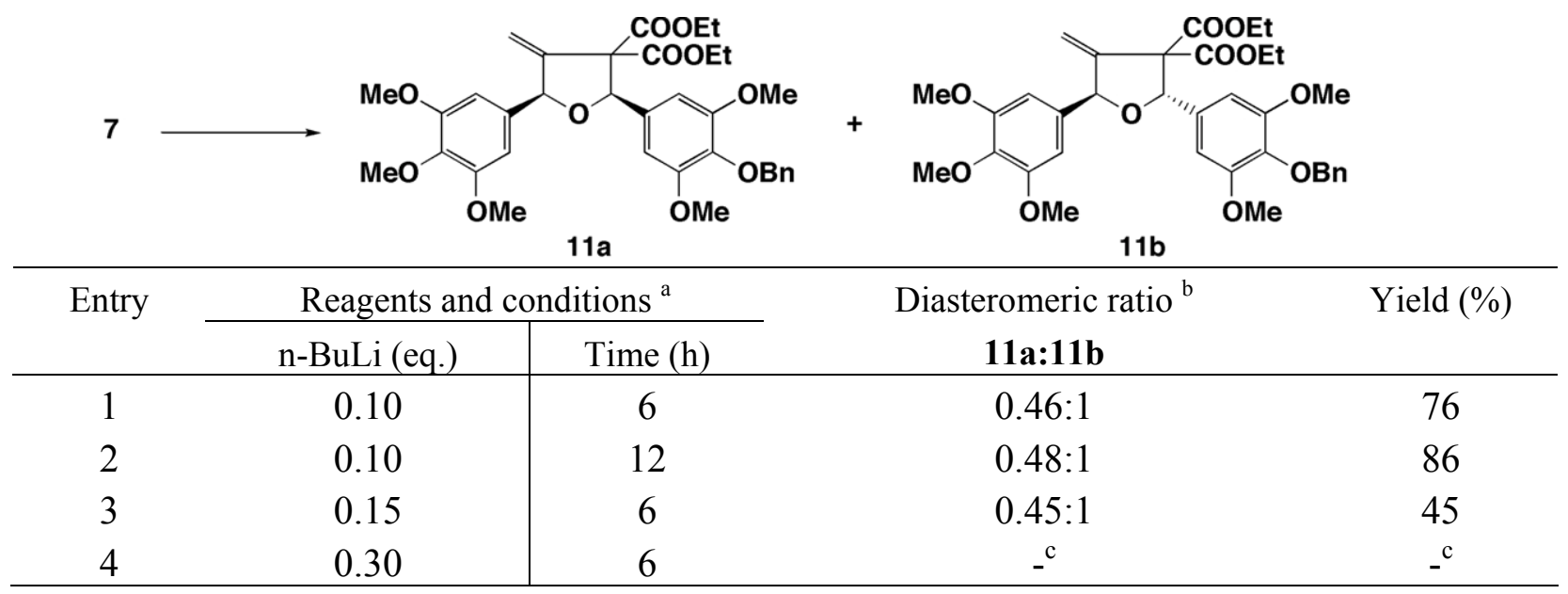

${ }^{\mathrm{a}} \mathrm{n}$-BuLi, THF, $0^{\circ} \mathrm{C}$-rt, then $\mathrm{Pd}(\mathrm{OAc})_{2}\left(0.05\right.$ eq.),TPP (0.05 eq.), 10 (1.5 eq.), THF. Rt. ${ }^{\mathrm{b}}$ Determined by ${ }^{1} \mathrm{H}-\mathrm{NMR}$ spectroscopy. ${ }^{\mathrm{c}}$ Complex mixture.

\section{Figure 2}

Allyl alcohol 14b, which was the major diastereoisomer of 14, was transformed in a twosteps sequence using tosylation with tosyl chloride ( $\mathrm{TsCl}$ ) and 4-(dimethylamino)pyridine (DMAP), followed by reduction with excess of $\mathrm{LiAlH}_{4}$ to yield 7,7'-dihydrofuran $\mathbf{1 6 b}$ (Scheme 4.). Catalytic hydrogenation of $\mathbf{1 6 b}$ with $\mathrm{Pd}(\mathrm{OH})_{2} / \mathrm{C}$ gave the phenol $\mathbf{1 7 b}$ by hydrogenolysis. In this step, we attempted to transform $\mathbf{1 6 b}$ to the desired THF lignan $\mathbf{1 8 b}$ directly, but this conversion was not possible under normal hydrogenation conditions due to the low reactivity at the hindered tetrasubstituted olefin. For example, the reaction with $\mathbf{1 6 b}$ by using $\mathrm{Pd}(\mathrm{OH})_{2}$ on carbon at room temperature (rt) for $48 \mathrm{~h}$ led to the formation of complex mixture as indicated by TLC.
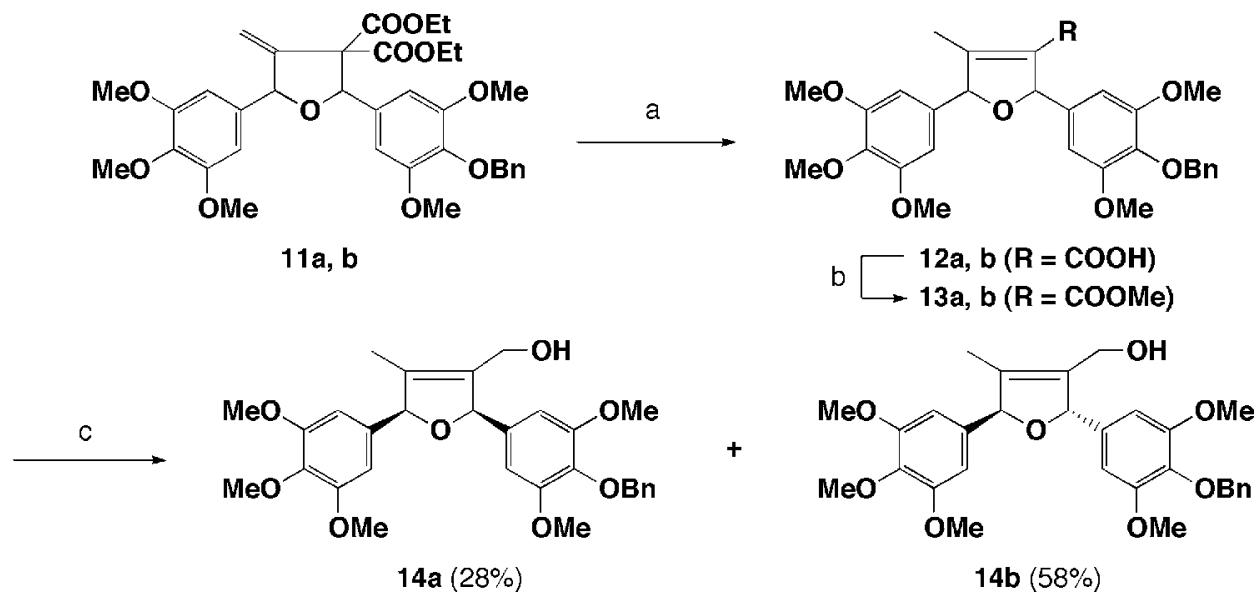

Reagents and conditions: (a) $1.0 \mathrm{M} \mathrm{NaOH}, 0^{\circ} \mathrm{C}-\mathrm{rt}$, then $1.0 \mathrm{M} \mathrm{HCl}, 90 \%$; (b) $\mathrm{MeI}, \mathrm{DBU}, \mathrm{MeCN}$, rt, quant.; (c) $\mathrm{LiAlH}_{4}, \mathrm{THF}, 0^{\circ} \mathrm{C}$-rt, then separation.

\section{Scheme 3}




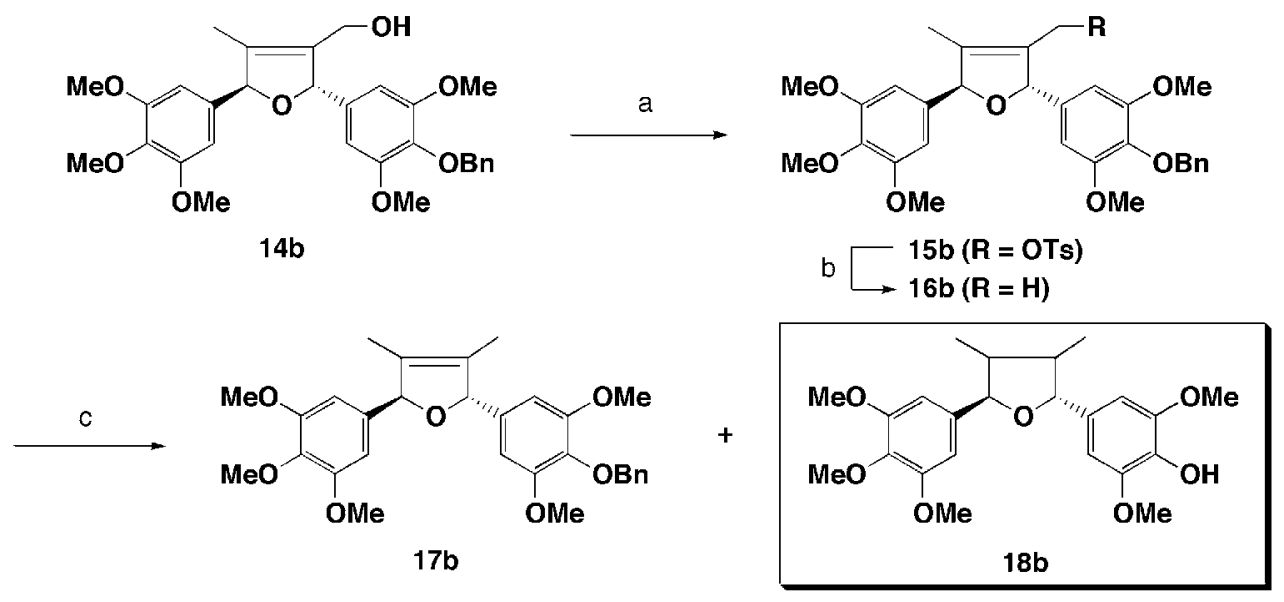

Reagents and conditions: (a) TsCl, DMAP, $0^{\circ} \mathrm{C}$,-rt; (b) $\mathrm{LiAlH}_{4}, \mathrm{THF}, 0^{\circ} \mathrm{C}-\mathrm{rt}, 52 \%$ (2steps); (c) $\mathrm{H} 2$ (1atm), $\mathrm{Pd}(\mathrm{OH})_{2}, \mathrm{AcOH}-\mathrm{MeOH}, \mathrm{rt}, 51 \%$

\section{Scheme 4}

The hydrogenation carried out on $\mathbf{1 6 b}$ indicated that the hydrogenolysis at the benzylic position is preferred over olefin reduction in the 7',7-dehydrofuran ring. In order to obtain original phenol derivatives, the synthetic intermediates 12 and $14 \mathrm{~b}$ were evaluated in this reaction (Scheme 5.) and the hydrogenolysis using with $\mathrm{Pd}(\mathrm{OH})_{2} / \mathrm{C}$ at $0{ }^{\circ} \mathrm{C}$, yielded the phenols 19 and $20 b$, respectively, in excellent yields.

Several conditions and reagents including $\mathrm{PtO}_{2}, \mathrm{Pd} / \mathrm{C}$, and Wilkinson's catalyst were attempted to reduce the tetra-substituted olefin. But it seems to be difficult to distinguish between hydrogenolysis at the benzyl group as a protective group and reduction of the tetrasubstituted olefin. Moreover, the obtained phenols (17b, 19a, 19b, and 20b) were quite labile under several hydrogenation conditions to produce tetrahydrofuran derivatives. In view of this drawback, the only alternative pathway to avoid hydrogenolysis at the secondary benzylic position involved the use of aldehyde $\mathbf{6}$ in the same sequence.
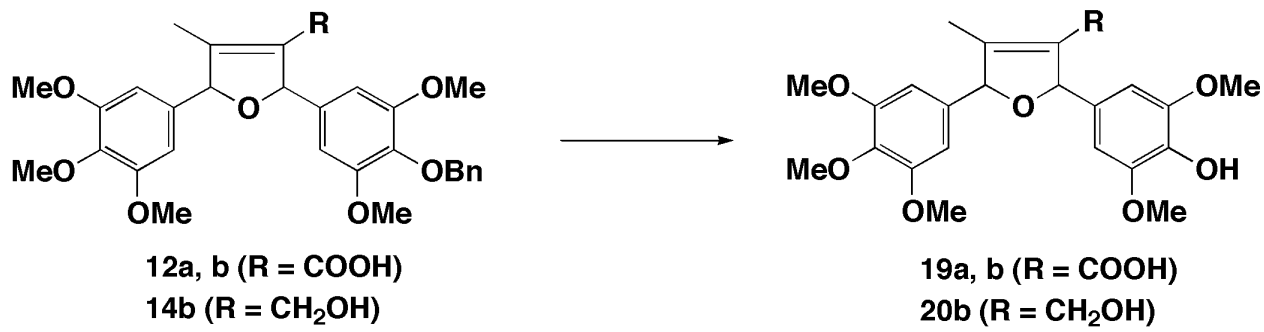

Reagents and conditions: $\mathrm{H}_{2}$ (1atm), $\mathrm{Pd}(\mathrm{OH})_{2}, \mathrm{AcOH}-\mathrm{MeOH}, 0^{\circ} \mathrm{C}, 84-95 \%$

\section{Scheme 5}


In short steps, the allyl alcohol 25a and 25b was obtained in high yield via the same steps (Scheme 6.). Although it was difficult to separate most of isomers of intermediates by using silica gel column chromatography, 25a and $\mathbf{2 5 b}$ exhibited excellent resolution without the application of preparative TLC.

Table 1. Tripomastigote lysis potency of the synthetic tetrahydrofuran lignans, intermediates and natural lignans

\begin{tabular}{cccccc}
\hline & \multicolumn{4}{c}{ Concentration $(\mu \mathrm{g} / \mathrm{mL}) \times$ x of lysis $( \pm \mathrm{SD})$} & \\
\cline { 2 - 5 } Compounds & 5.0 & 50.0 & 100.0 & 500.0 & $\mathrm{IC}_{50}(\mu \mathrm{M})$ \\
\hline $\mathbf{7}$ & $12.5 \pm 8$ & $47.1 \pm 7$ & $53.3 \pm 8$ & $64.3 \pm 8$ & 429.3 \\
10a & $33.9 \pm 8$ & $48.2 \pm 11$ & $62.5 \pm 6$ & $87.9 \pm 8$ & 75.0 \\
11a & $0.0 \pm$ & $20.1 \pm 9$ & $31.9 \pm 6$ & $40.9 \pm 5$ & 1242.2 \\
11b & $16.1 \pm 3$ & $35.7 \pm 0$ & $45.5 \pm 5$ & $48.2 \pm 8$ & 580.0 \\
12a & 0.0 & $16.0 \pm 6$ & $21.4 \pm 3$ & $25.7 \pm 7$ & 9622.0 \\
12b & $21.4 \pm 3$ & $24.1 \pm 4$ & $25.0 \pm 5$ & $63.4 \pm 9$ & 580.0 \\
13a, b & $14.3 \pm 5$ & $36.1 \pm 2$ & $42.9 \pm 1$ & $56.5 \pm 7$ & 68.7 \\
14a & $20.9 \pm 4$ & $31.1 \pm 2$ & $41.2 \pm 2$ & $39.5 \pm 1$ & 51.2 \\
14b & $57.1 \pm 8$ & $66.6 \pm 6$ & $67.2 \pm 10$ & $74.0 \pm 2$ & 1.5 \\
16a, b & $19.8 \pm 5$ & $37.8 \pm 5$ & $45.2 \pm 11$ & $50.3 \pm 2$ & 84.2 \\
18 & $12.5 \pm 8$ & $47.3 \pm 7$ & $53.3 \pm 8$ & $64.3 \pm 8$ & 439.3 \\
19a & $46.9 \pm 13$ & $48.0 \pm 2$ & $68.4 \pm 12$ & $77.4 \pm 4$ & 10.4 \\
19b & $5.1 \pm 3$ & $31.1 \pm 2$ & $34.5 \pm 4$ & $39.5 \pm 1$ & 160.6 \\
20b & $16.4 \pm 5$ & $40.7 \pm 5$ & $40.7 \pm 7$ & $44.15 \pm 4$ & 127.0 \\
21 & $33.9 \pm 8$ & $48.2 \pm 11$ & $62.5 \pm 5$ & $87.5 \pm 8$ & 75.0 \\
23a/23b & $46.9 \pm 12$ & $55.9 \pm 6$ & $61.6 \pm 5$ & $74.0 \pm 8$ & 9.0 \\
24a/24b & $16.4 \pm 5$ & $7.8 \pm 8$ & $30.0 \pm 4$ & $41.2 \pm 5$ & 278.0 \\
25a/25b & $11.9 \pm 9$ & $24.9 \pm 3$ & $37.8 \pm 7$ & $52.6 \pm 0$ & 93.0 \\
\hline
\end{tabular}

Positive control - Violet Gentian $(250 \mu / \mathrm{mL})$, negative control - infected blood + $5 \%$ DMSO. 


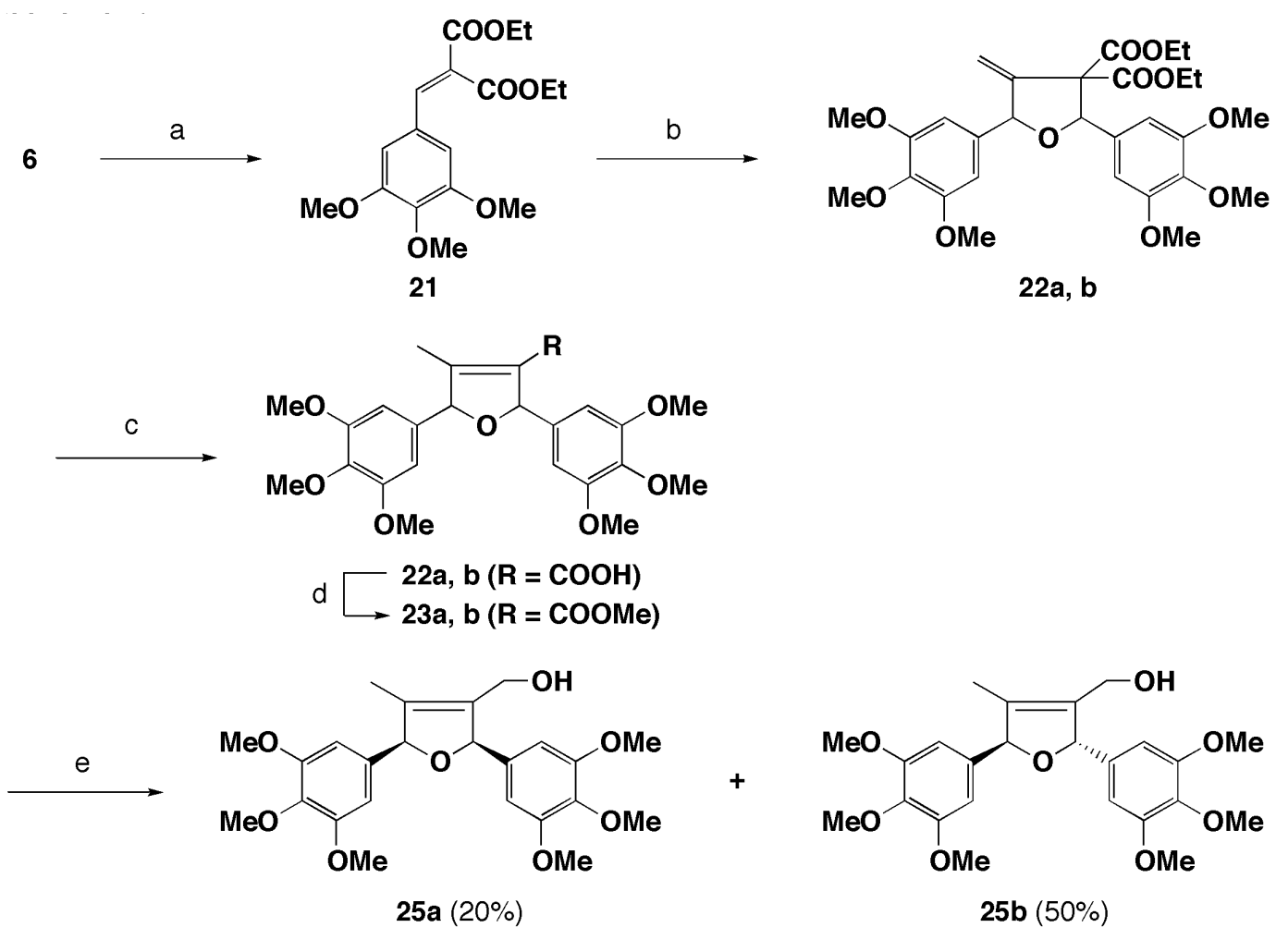

Reagents and conditions: (a) diethyl malonate, $\mathrm{AcOH}$, pyrrolidine, toluene, $\Delta, 75 \%$; (b) 7, nBuLi, THF, $0^{\circ} \mathrm{C}$-rt then 21, Pd(OAc) $)_{2}$ TPP, rt, 92\% (22a:22b=1:2); (c) $1.0 \mathrm{M} \mathrm{NaOH}, 0^{\circ} \mathrm{C}-\mathrm{rt}$, $85 \%$; (d) MeI, DBU, MeCN, rt, quant.; (c) $\mathrm{LiAlH}_{4}$, THF, $0^{\circ} \mathrm{C}-\mathrm{rt}$, then separation.

\section{Scheme 6}

The first synthesis of 7,7'-dehydrofuran $\mathbf{1 7 b}$ was accomplished by using a convergent strategy via nine steps in $9 \%$ total yield from syringaldehyde (8). Then, from aldehyde $\mathbf{6}$, allyl alcohol 25a and 25b were obtained in $41 \%$ total yield. The advantage of the reaction sequence can be summarized by two points. One is the facile induction of several moieties at THF ring. The second is the possibility to scale up this synthesis at inexpensive cost using a catalytic amount and easily available reagents.

The evaluation of trypanocidal activity was carried out according to the procedure described in the literature (Table 1) ${ }^{21}$. In comparison with grandisin (1) and veraguensin (2) which exhibited total tripomastigote lysis at the concentration of 3.7 and $2.3 \mu \mathrm{M}$, all synthetic lignans showed lower activities, except for the lignan $\mathbf{1 4 b}$ in which a $\mathrm{IC}_{50}$ of $1.5 \mu \mathrm{M}$ was determined. The trans configuration between aromatic ring seems to be an important requirement for activity since 11b and 14b were more active than the corresponding 11a and 14a, although for veraguensin (cis) and grandisin (trans) no significant difference could be observed.

Since the tetrahydrofuran lignans have showed promising trypanocidal activity ${ }^{13-15}$, further systematic investigations are required for a better evaluation of this potential. 


\section{Experimental Section}

General Procedures. EI-MS were measured at $70 \mathrm{eV}$ on a HP 5990/5988 A spectrometer. ${ }^{1} \mathrm{H}$ and ${ }^{13} \mathrm{C}$ NMR spectra were measured on a Bruker DPX-300 (300 and $75 \mathrm{MHz}$ ) while 2D experiments (HMQC and HMBC) were recorded in a Bruker DRX-500 (500 and $125 \mathrm{MHz}$ ) using $\mathrm{CDCl}_{3}$ (Aldrich) as solvent and TMS as int. standard. Chemical shifts were reported in units (ppm) and coupling constants $(J)$ in Hz. ESI analysis were performed on a triple quadrupole (Quattro-LC, Micromass, UK). Dilute standards (10mg ml-1) were prepared daily in $80 \% \mathrm{v} / \mathrm{v}$ (methanol/water) with $0.25 \mathrm{mg} \mathrm{ml}-1$ as the final concentration. Routine TLC analysis were performed Silica gel (Merck, 70-230 mesh) was used for CC and silica-gel $60 \mathrm{PF}_{254}$ Merck (0.50 $\mathrm{mm}$ and $1 \mathrm{~mm}$ ) for anal. and prep. TLC. Spots on chromatograms were detected under UV light ( 254 and $365 \mathrm{~nm}$ ) and by spraying $\mathrm{H}_{2} \mathrm{SO}_{4} 60 \%$ and ceric sulphate solutions followed by heating.

Propargyl alcohol (7). To a cold $\left(0^{\circ} \mathrm{C}\right)$ and stirred solution of 3,4,5-trimethoxybenzaldehyde $(6$, $1.0 \mathrm{~g}, 5.10 \mathrm{mmol})$ in THF $(20 \mathrm{~mL})$ was added dropwise over a period of $10 \mathrm{~min}$, ethynylmagnesium bromide $(15.0 \mathrm{~mL}, 0.5 \mathrm{M}$ solution in THF, $7.50 \mathrm{mmol})$. After $10 \mathrm{~min}$ of stirring at $0{ }^{\circ} \mathrm{C}$, the resultant solution was allowed to warm to room temperature and stirred for another $2 \mathrm{~h}$. The mixture was poured into AcOEt $(200 \mathrm{~mL})$ and washed with a saturated aqueous $\mathrm{NH}_{4} \mathrm{Cl}$ solution $(3 \times 25 \mathrm{~mL})$ and brine $(3 \times 25 \mathrm{~mL})$. The aqueous layers were extracted with AcOEt $(3 \times 50 \mathrm{~mL})$, and the combined organic layers were dried over $\mathrm{Na}_{2} \mathrm{SO}_{4}$. Filtration and concentration followed by silica gel chromatography (20-40\% AcOEt in hexane) gave $0.94 \mathrm{~g}$ (83\%) of propargyl alcohol 7 as a colorless solid: $128-133{ }^{\circ} \mathrm{C} ;{ }^{1} \mathrm{H}$ NMR $\left(300 \mathrm{MHz}, \mathrm{CDCl}_{3}\right): \delta$ $2.68(\mathrm{~d}, 1 \mathrm{H}, J=2.1 \mathrm{~Hz}), 2.75(\mathrm{~d}, 1 \mathrm{H}, J=5.7 \mathrm{~Hz}), 3.82(\mathrm{~s}, 3 \mathrm{H}), 3.87(\mathrm{~s}, 6 \mathrm{H}), 5.40(\mathrm{dd}, 1 \mathrm{H}, J=$ 2.1, 5.7 Hz), and 6.87 (s, 2H); ${ }^{13} \mathrm{C} \mathrm{NMR}\left(75 \mathrm{MHz}, \mathrm{CDCl}_{3}\right): \delta 5.60,60.7,64.3,74.7,83.5,103.6$, 135.7, 137.9, 153.2.

Benzyl ether (9). To a stirred solution of syringaldehyde (8, $1.0 \mathrm{~g}, 5.49 \mathrm{mmol})$ in DMF (10 mL) at $\mathrm{rt}$ was added benzyl bromide $(1.41 \mathrm{~g}, 8.24 \mathrm{mmol})$ and $\mathrm{K}_{2} \mathrm{CO}_{3}(0.84 \mathrm{~g}, 6.08 \mathrm{mmol})$. The resultant suspension was warmed to $75^{\circ} \mathrm{C}$, and stirring was continued for $10 \mathrm{~h}$. The mixture was cooled to $\mathrm{rt}$ and then poured into AcOEt $(300 \mathrm{~mL})$, and washed with water $(3 \mathrm{x} 50 \mathrm{~mL})$, and brine $(3 \times 50 \mathrm{~mL})$. The aqueous layers were extracted with AcOEt $(3 \times 50 \mathrm{~mL})$, and the combined organic layers were dried over $\mathrm{Na}_{2} \mathrm{SO}_{4}$. Filtration and concentration followed by silica gel chromatography (5-15\% AcOEt in hexane) gave $1.45 \mathrm{~g}$ (97\%) of benzyl ether 9 as colorless oil. The analytical data were consistent with those in the previous report ${ }^{23}$.

Arylidenemalonate (10). To a solution of benzyl ether $9(0.50 \mathrm{~g}, 1.84 \mathrm{mmol})$ in toluene $(10 \mathrm{~mL})$ at $\mathrm{rt}$ was added ethyl malonate $(0.30 \mathrm{~g}, 1.87 \mathrm{mmol}), \mathrm{AcOH}(30 \mathrm{mg}, 0.50 \mathrm{mmol})$ and pyrrolidine $(15 \mathrm{mg}, 0.21 \mathrm{mmol})$. The resultant solution was reflux for $4 \mathrm{~h}$, and cooled to $\mathrm{rt}$. The mixture was poured into AcOEt $(200 \mathrm{~mL})$, and washed with water $(3 \times 50 \mathrm{~mL})$, and brine $(3 \times 50 \mathrm{~mL})$. The aqueous layers were extracted with AcOEt $(3 \times 50 \mathrm{~mL})$, and the combined organic layers were dried over $\mathrm{Na}_{2} \mathrm{SO}_{4}$. Filtration and concentration followed by silica gel chromatography (50\% $\mathrm{CH}_{2} \mathrm{Cl}_{2}$ in hexane-100\% $\mathrm{CH}_{2} \mathrm{Cl}_{2}-2 \%$ AcOEt in $\mathrm{CH}_{2} \mathrm{Cl}_{2}$ ) gave $0.61 \mathrm{~g}(80 \%)$ of arylidenemalonate 
10 as a colorless oil: ${ }^{1} \mathrm{H}$ NMR $\left(300 \mathrm{MHz}, \mathrm{CDCl}_{3}\right): \delta 1.30(\mathrm{t}, 3 \mathrm{H}, J=6.9 \mathrm{~Hz}), 1.33(\mathrm{t}, 3 \mathrm{H}, J=6.9$ $\mathrm{Hz}), 3.81$ (s, 6H), 4.30 (q, 2H, $J=6.9 \mathrm{~Hz}), 4.33$ (q, 2H, J=6.9 Hz), 5.05 (s, 2H), 6.72 (s, 2H), $7.31(\mathrm{~m}, 3 \mathrm{H}), 7.45(\mathrm{~m}, 2 \mathrm{H})$, and $7.64(\mathrm{~s}, 1 \mathrm{H}) ;{ }^{13} \mathrm{C} \mathrm{NMR}\left(75 \mathrm{MHz}, \mathrm{CDCl}_{3}\right): \delta 13.9,14.1,56.0$, $61.5,61.6,75.0,106.9,125.3,127.9,128.1,128.3,128.4,137.4,139.1,142.0,153.5,164.1$, 166.9. ESI $[\mathrm{M}+1]^{+} 421$.

Methylenetetrahydrofurans (11a and 11b). $n-\operatorname{BuLi}(58 \mu \mathrm{L}, 1.6 \mathrm{M}$ solution in hexane, $93 \mu \mathrm{mol})$ was added dropwise to a cooled $\left(0{ }^{\circ} \mathrm{C}\right)$ and stirred solution of propargyl alcohol 7 (311 $\mathrm{mg}$, $1.40 \mathrm{mmol})$ in THF $(2.5 \mathrm{~mL})$ and then the reaction mixture was allowed to reach $\mathrm{rt}$ for $15 \mathrm{~min}$. The solution of arylidenemalonate $10(387 \mathrm{mg}, 0.93 \mathrm{mmol})$ in THF $(3.0 \mathrm{~mL})$ was then added followed by both $\mathrm{Pd}(\mathrm{OAc})_{2}(10.4 \mathrm{mg}, 46.3 \mu \mathrm{mol})$ and TPP $(12.1 \mathrm{mg}, 46.1 \mu \mathrm{mol})$. Stirring was continued for $12 \mathrm{~h}$ and poured into $\mathrm{AcOEt}(100 \mathrm{~mL})$, and washed with saturated aqueous $\mathrm{NH}_{4} \mathrm{Cl}$ solution ( $3 \times 20 \mathrm{~mL})$, and brine $(3 \times 20 \mathrm{~mL})$. The aqueous layers were extracted with AcOEt (3 x $20 \mathrm{~mL}$ ), and the combined organic layers were dried over $\mathrm{Na}_{2} \mathrm{SO}_{4}$. Filtration and concentration followed by silica gel chromatography (20-30\% AcOEt in hexane) gave $0.51 \mathrm{~g}(86 \%)$ of methylenetetrahydrofurans 11a and 11b (diastereomeric ratio was 0.48:1 which was determined by ${ }^{1} \mathrm{H}-\mathrm{NMR}$ experiment) as a colorless oil: Analytical and bioassay sample was purified by using preparative TLC.

11a. $R_{f} 0.53$ (40\% AcOEt in hexane); ${ }^{1} \mathrm{H}-\mathrm{NMR}\left(300 \mathrm{MHz}, \mathrm{CDCl}_{3}\right): \delta 0.82(\mathrm{t}, 3 \mathrm{H}, J=6.9 \mathrm{~Hz})$, $1.31(\mathrm{t}, 3 \mathrm{H}, J=6.9 \mathrm{~Hz}), 3.43(\mathrm{dq}, 1 \mathrm{H}, J=6.9,10.8 \mathrm{~Hz}), 3.81(\mathrm{~s}, 6 \mathrm{H}), 3.82(\mathrm{dq}, 1 \mathrm{H}, 6.9,10.8 \mathrm{~Hz})$, $3.88(\mathrm{~s}, 3 \mathrm{H}), 3.90(\mathrm{~s}, 6 \mathrm{H}), 4.31(\mathrm{q}, 2 \mathrm{H}, J=6.9 \mathrm{~Hz}), 4.99(\mathrm{~s}, 2 \mathrm{H}), 5.03(\mathrm{~d}, 1 \mathrm{H}, J=2.7 \mathrm{~Hz}), 5.30$ $(\mathrm{d}, 1 \mathrm{H}, J=2.7 \mathrm{~Hz}), 5.62(\mathrm{t}, 1 \mathrm{H}, J=2.7 \mathrm{~Hz}), 5.76(\mathrm{~s}, 1 \mathrm{H}), 6.79(\mathrm{~s}, 2 \mathrm{H}), 6.93(\mathrm{~s}, 2 \mathrm{H}), 7.30(\mathrm{~m}$, $3 \mathrm{H})$, and $7.70(\mathrm{~m}, 2 \mathrm{H}) ;{ }^{13} \mathrm{C}-\mathrm{NMR}\left(75 \mathrm{MHz}, \mathrm{CDCl}_{3}\right): \delta 13.6,14.0,56.0,56.1,60.8,61.4,61.9$, $68.9,75.0,83.7,84.0,104.0,106.0,113.6,127.8,128.1,128.6,132.6,135.1,136.6,137.7,138.2$, $149.3,153.0,153.2,168.1,168.4$. ESI $[\mathrm{M}+1]^{+} 637$.

11b. $R_{f} 0.52$ (40\% AcOEt in hexane); ${ }^{1} \mathrm{H} \mathrm{NMR}\left(300 \mathrm{MHz}, \mathrm{CDCl}_{3}\right): \delta 0.85(\mathrm{t}, 3 \mathrm{H}, J=7.2 \mathrm{~Hz})$, $1.30(\mathrm{t}, 3 \mathrm{H}, J=7.2 \mathrm{~Hz}), 3.54(\mathrm{dq}, 1 \mathrm{H}, J=7.2,10.5 \mathrm{~Hz}), 3.82(\mathrm{~s}, 6 \mathrm{H}), 3.84(\mathrm{dq}, 1 \mathrm{H}, J=7.2,10.5$ $\mathrm{Hz}), 3.85$ (s, 3H), 3.87 (s, 6H), 4.31 (q, 2H, J=7.2 Hz), 4.98 (s, 2H), 5.25 (d, 1H, J = 2.1 Hz), $5.69(\mathrm{~d}, 1 \mathrm{H}, J=2.1 \mathrm{~Hz}), 5.86(\mathrm{t}, 1 \mathrm{H}, J=2.1 \mathrm{~Hz}), 5.92(\mathrm{~s}, 1 \mathrm{H}), 6.62(\mathrm{~s}, 2 \mathrm{H}), 6.73(\mathrm{~s}, 2 \mathrm{H}), 7.30$ $(\mathrm{m}, 3 \mathrm{H})$, and $7.70(\mathrm{~m}, 2 \mathrm{H}) ;{ }^{13} \mathrm{C} \mathrm{NMR}\left(75 \mathrm{MHz}, \mathrm{CDCl}_{3}\right): \delta 13.6,14.0,56.1,60.8,61.6,62.0$, 69.0, 75.0, 83.8, 83.9, 104.0, 104.5, 113.8, 127.8, 128.1, 128.6, 133.1, 136.1, 136.6, 137.7, 137.8, 147.8, 153.1, 153.3, 167.6, 167.8. ESI [M+1] 637.

Carboxylic acids (12a and 12b). To a cold $\left(\begin{array}{lll}0 & \left.{ }^{\circ} \mathrm{C}\right)\end{array}\right)$ and stirred solution of methylenetetrahydrofurans 11a and $11 \mathbf{b}(200 \mathrm{mg}, 0.31 \mathrm{mmol})$ in $\mathrm{MeOH}(8 \mathrm{~mL})$ was added dropwise $5.0 \mathrm{M}$ aqueous $\mathrm{NaOH}$ solution $(2.0 \mathrm{~mL}, 10 \mathrm{mmol})$, and the resultant solution was stirred for $12 \mathrm{~h}$ at $\mathrm{rt}$. After cooling to $0{ }^{\circ} \mathrm{C}$ and treating $1.0 \mathrm{M}$ aqueous $\mathrm{HCl}$ solution until $\mathrm{pH} 3$, the reaction mixture was concentrated in vacuo. The crude was dissolved with AcOEt $(50 \mathrm{~mL})$, and washed with $1 \%$ aqueous $\mathrm{HCl}$ solution $(3 \times 10 \mathrm{~mL})$ and brine $(3 \times 10 \mathrm{~mL})$. The aqueous layer was extracted with AcOEt $(3 \times 10 \mathrm{~mL})$, and the combined organic layer was dried over $\mathrm{Na}_{2} \mathrm{SO}_{4}$. Filtration and concentration followed by silica gel chromatography $(1-6 \% \mathrm{MeOH}$ in $\mathrm{CH}_{2} \mathrm{Cl}_{2}$ ) gave $152 \mathrm{mg}(90 \%)$ of carboxylic acids $\mathbf{1 2 a}$ and $\mathbf{1 2 b}$. The sample for analysis and 
bioassay was purified by preparative TLC.

12a. Colorless solid, mp $130-134^{\circ} \mathrm{C}(\mathrm{MeOH}) ; R_{f} 0.55-0.40$ (70\% AcOEt in hexane), $R_{f} 0.47$ (5\% $\mathrm{MeOH}$ in $\mathrm{CH}_{2} \mathrm{Cl}_{2}$ ); ${ }^{1} \mathrm{H}-\mathrm{NMR}\left(300 \mathrm{MHz}, \mathrm{CDCl}_{3}\right): \delta 2.07$ (dd, $\left.3 \mathrm{H}, J=0.6,2.1 \mathrm{~Hz}\right), 3.77(\mathrm{~s}, 6 \mathrm{H})$, 3.79 (s, 6H), $3.81(\mathrm{~s}, 3 \mathrm{H}), 4.97(\mathrm{~s}, 2 \mathrm{H}), 5.62(\mathrm{dd}, 1 \mathrm{H}, J=0.6,3.9 \mathrm{~Hz}), 5.98(\mathrm{dd}, 1 \mathrm{H}, J=2.1,3.9$ $\mathrm{Hz}), 6.51(\mathrm{~s}, 2 \mathrm{H}), 6.65(\mathrm{~s}, 2 \mathrm{H}), 7.31(\mathrm{~m}, 3 \mathrm{H})$, and $7.47(\mathrm{~m}, 2 \mathrm{H})$.

12b. Colorless solid, mp $129-132^{\circ} \mathrm{C}(\mathrm{MeOH}) ; R_{f} 0.67-0.55$ (70\% AcOEt in hexane), $R_{f} 0.48(5 \%$ $\mathrm{MeOH}$ in $\left.\mathrm{CH}_{2} \mathrm{Cl}_{2}\right) ;{ }^{1} \mathrm{H} \mathrm{NMR}\left(300 \mathrm{MHz}, \mathrm{CDCl}_{3}\right): \delta 2.05(\mathrm{dd}, 3 \mathrm{H}, J=0.9,1.5 \mathrm{~Hz}), 3.82(\mathrm{~s}, 6 \mathrm{H})$, $3.85(\mathrm{~s}, 3 \mathrm{H}), 3.87(\mathrm{~s}, 6 \mathrm{H}), 4.99(\mathrm{~s}, 2 \mathrm{H}), 5.80(\mathrm{dd}, 1 \mathrm{H}, J=0.9,5.4 \mathrm{~Hz}), 6.12(\mathrm{dd}, 1 \mathrm{H}, J=1.5$, $5.4 \mathrm{~Hz}), 6.52(\mathrm{~s}, 2 \mathrm{H}), 6.60(\mathrm{~s}, 2 \mathrm{H}), 7.30(\mathrm{~m}, 3 \mathrm{H})$, and $7.48(\mathrm{~m}, 2 \mathrm{H}) ;{ }^{13} \mathrm{C} \mathrm{NMR}\left(75 \mathrm{MHz}, \mathrm{CDCl}_{3}\right)$ :

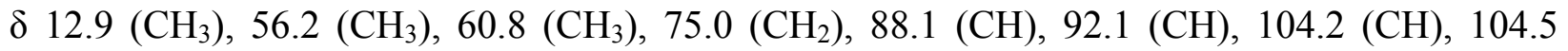
$(\mathrm{CH}), 126.9(\mathrm{C}), 127.8(\mathrm{CH}), 128.1(\mathrm{CH}), 128.4(\mathrm{CH}), 134.7(\mathrm{C}), 136.3(\mathrm{C}), 137.2(\mathrm{C}), 137.8$ (C), 138.3 (C), 153.5 (C), 153.6 (C), 155.4 (C), and 168.1 (C); ESI [M-1] 635.

Esters (13a and 13b). To a solution of carboxylic acids 12a and 12b (0.10 g, $0.19 \mathrm{mmol})$ in MeCN (2 mL) at $\mathrm{rt}$ was added MeI (109 mg, $0.77 \mathrm{mmol})$ and DBU (58 mg, $0.38 \mathrm{mmol})$. After stirring for $1 \mathrm{~h}$, the reaction mixture was concentrated in vacuo. The crude was dissolved with AcOEt $(50 \mathrm{~mL})$, and washed with water $(3 \times 10 \mathrm{~mL})$ and brine $(3 \times 10 \mathrm{~mL})$. The aqueous layer was extracted with AcOEt ( $3 \times 10 \mathrm{~mL}$ ), and the combined organic layer was dried over $\mathrm{Na}_{2} \mathrm{SO}_{4}$. Filtration and concentration followed by silica gel chromatography (20-40\% AcOEt in hexane) gave $103 \mathrm{mg}$ (quant.) of esters $\mathbf{1 3 a}$ and $\mathbf{1 3 b}$ as a colorless oil. The samples for analysis were purified by preparative TLC.

13a. $R_{f} 0.46$ (40\% AcOEt in hexane); ${ }^{1} \mathrm{H}$ NMR (300 MHz, $\left.\mathrm{CDCl}_{3}\right): \delta 2.04(\mathrm{dd}, 3 \mathrm{H}, J=0.6,2.1$ Hz), 3.67 (s, 3H), 3.77 (s, 6H), 3.79 (s, 6H), 3.81 (s, 3H), 4.98 (s, 2H), 5.60 (dq, 1H, J = 0.6, 4.5 $\mathrm{Hz}), 5.99(\mathrm{dq}, 1 \mathrm{H}, J=2.1,4.5 \mathrm{~Hz}), 6.51(\mathrm{~s}, 2 \mathrm{H}), 6.62(\mathrm{~s}, 2 \mathrm{H}), 7.31(\mathrm{~m}, 3 \mathrm{H})$, and $7.47(\mathrm{~m}, 2 \mathrm{H})$; ${ }^{13} \mathrm{C}-\mathrm{NMR}\left(75 \mathrm{MHz}, \mathrm{CDCl}_{3}\right): \delta 13.1,51.7,56.4,56.5,60.7,75.2,87.8,92.0,105.1,105.4,127.5$, $128.1,128.4,128.7,135.0,136.9,138.1,138.2,138.5,153.1,153.7,153.8$ and 164.1. ESI $[\mathrm{M}+1]^{+} 551$.

13b. $R_{f} 0.47\left(40 \%\right.$ AcOEt in hexane; ${ }^{1} \mathrm{H}$ NMR (300 MHz, $\left.\mathrm{CDCl}_{3}\right): \delta 2.04(\mathrm{dd}, 3 \mathrm{H}, J=0.6,1.8$ $\mathrm{Hz}), 3.70(\mathrm{~s}, 3 \mathrm{H}), 3.84(\mathrm{~s}, 6 \mathrm{H}), 3.85$ (s, 3H), $3.88(\mathrm{~s}, 6 \mathrm{H}), 5.00(\mathrm{~s}, 2 \mathrm{H}), 5.79$ (dq, 1H, J = 0.6, 5.4 $\mathrm{Hz}), 6.14(\mathrm{dq}, 1 \mathrm{H}, J=1.8,5.4 \mathrm{~Hz}), 6.54(\mathrm{~s}, 2 \mathrm{H}), 6.59(\mathrm{~s}, 2 \mathrm{H}), 7.32(\mathrm{~m}, 3 \mathrm{H})$, and $7.48(\mathrm{~m}, 2 \mathrm{H})$; ${ }^{13} \mathrm{C}$ NMR $\left(75 \mathrm{MHz} \mathrm{CDCl}_{3}\right): \delta 12.7,51.5,56.3,60.9,75.0,88.4,92.2,104.3,104.4,127.5,127.8$, $128.2,128.5,135.1,136.7,137.4,138.0,138.4,152.5,153.6,153.7$, and 164.1. ESI [M+1] ${ }^{+} 551$.

Allyl alcohol (14a and 14b). To a cold $\left(0{ }^{\circ} \mathrm{C}\right)$ and stirred solution of esters 13a and $13 \mathbf{b}$ (72 $\mathrm{mg}$, $0.13 \mathrm{mmol})$ in THF $(2 \mathrm{~mL})$ was slowly added $\mathrm{LiAlH}_{4}(30 \mathrm{mg}, 0.79 \mathrm{mmol})$. After $10 \mathrm{~min}$ of stirring at $0{ }^{\circ} \mathrm{C}$, the resultant solution was allowed to warm to room temperature and stirred for another $2 \mathrm{~h}$. The mixture was treated with AcOEt $(1 \mathrm{ml})$ at $0{ }^{\circ} \mathrm{C}$ and filtered through a pad of celite. The filtration was concentrated in vacuo, and then chromatographed on silica gel (20-40\% AcOEt in hexane) gave allyl alcohol 14a (19 mg, 28\%) and $\mathbf{1 4 b}(40 \mathrm{mg}, 58 \%)$ as a colorless oil. 14 ${ }^{\mathrm{a}} . R_{f} 0.40$ (60\% AcOEt in hexane); $\left.{ }^{1} \mathrm{H} \mathrm{NMR} \mathrm{(300} \mathrm{MHz,} \mathrm{CDCl}_{3}\right): \delta 1.71(\mathrm{~s}, 3 \mathrm{H}), 3.78(\mathrm{~s}, 6 \mathrm{H})$, $3.82(\mathrm{~s}, 6 \mathrm{H}), 3.83(\mathrm{~s}, 3 \mathrm{H}), 4.08(\mathrm{dd}, 1 \mathrm{H}, J=2.1,12.6 \mathrm{~Hz}), 4.35(\mathrm{~d}, 1 \mathrm{H}, J=12.6 \mathrm{~Hz}), 4.99(\mathrm{~s}, 2 \mathrm{H})$, $5.57(\mathrm{~d}, 1 \mathrm{H}, J=2.1 \mathrm{~Hz}), 5.83(\mathrm{~m}, 1 \mathrm{H}), 6.57(\mathrm{~s}, 2 \mathrm{H}), 6.64(\mathrm{~s}, 2 \mathrm{H}), 7.31(\mathrm{~m}, 3 \mathrm{H})$, and $7.47(\mathrm{~m}$, 
$2 \mathrm{H})$. ESI $[\mathrm{M}+1]^{+} 523$.

14b. $R_{f} 0.50$ (60\% AcOEt in hexane); ${ }^{1} \mathrm{H}$ NMR (300 MHz, $\left.\mathrm{CDCl}_{3}\right): \delta 1.67(\mathrm{~d}, 3 \mathrm{H}, J=2.1 \mathrm{~Hz})$, $3.84(\mathrm{~s}, 6 \mathrm{H}), 3.85(\mathrm{~s}, 3 \mathrm{H}), 3.88(\mathrm{~s}, 6 \mathrm{H}), 4.01(\mathrm{dd}, 1 \mathrm{H}, J=1.5,12.3 \mathrm{~Hz}), 4.32(\mathrm{~d}, 1 \mathrm{H}, J=12.3 \mathrm{~Hz})$, $5.01(\mathrm{~s}, 2 \mathrm{H}), 5.74(\mathrm{dd}, 1 \mathrm{H}, J=1.5,5.4 \mathrm{~Hz}), 6.00(\mathrm{dd}, 1 \mathrm{H}, J=2.1,5.4 \mathrm{~Hz}), 6.57(\mathrm{~s}, 2 \mathrm{H}), 6.60$ (s, $2 \mathrm{H}), 7.31(\mathrm{~m}, 3 \mathrm{H})$, and $7.48(\mathrm{~m}, 2 \mathrm{H}) ;{ }^{13} \mathrm{C} \mathrm{NMR}(75 \mathrm{MHz}, \mathrm{CDCl} 3): \delta 10.6,56.2,56.3,60.8,75.0$, 89.3, 91.8, 103.8, 103.9, 127.8, 128.1, 128.5, 134.4, 135.0, 136.3, 136.8, 137.0, 137.7, 137.9, 153.4, and 153.8. ESI $[\mathrm{M}+1]^{+} 523$.

7,7'-Dehydrofuran (16b). To a solution of allyl alcohol $14 b(50 \mathrm{mg}, 95.7 \mu \mathrm{mol})$ in $\mathrm{CH}_{2} \mathrm{Cl}_{2}$ $(1.0 \mathrm{~mL})$ was added DMAP $(23 \mathrm{mg}, 0.19 \mathrm{mmol})$. To the cold $\left(0{ }^{\circ} \mathrm{C}\right)$ and vigorously stirred solution was slowly added $\mathrm{TsCl}(36 \mathrm{mg}, 0.19 \mathrm{mmol})$. After $12 \mathrm{~h}$ of stirring at $\mathrm{rt}$, the reaction mixture was poured into AcOEt $(20 \mathrm{~mL})$, and washed water $(3 \times 5 \mathrm{~mL})$ and brine $(3 \times 5 \mathrm{~mL})$. The aqueous layers were extracted with $\operatorname{AcOEt}(3 \times 10 \mathrm{~mL})$, and the combined organic layers were dried over $\mathrm{Na}_{2} \mathrm{SO}_{4}$. Filtration and concentration gave the desired crude sulfonate ester $\mathbf{1 5 b}$ as a colorless oil, which was used in the next step without further purification.

To a cold $\left(0{ }^{\circ} \mathrm{C}\right)$ and stirred solution of crude sulfonate ester in THF $(2.0 \mathrm{~mL})$ was slowly added $\mathrm{LiAlH}_{4}(22 \mathrm{mg}, 1.58 \mathrm{mmol})$. After $10 \mathrm{~min}$ of stirring at $0{ }^{\circ} \mathrm{C}$, the reaction mixture was allowed to warm to room temperature and stirred for another $5 \mathrm{~h}$. The mixture was treated with AcOEt $(1 \mathrm{ml})$ at $0{ }^{\circ} \mathrm{C}$ and filtered through a pad of celite. The filtration was concentrated in vacuo, and then chromatographed on silica gel (10-30\% AcOEt in hexane) gave $25 \mathrm{mg}(52 \%, 2$ steps) of 7,7'-dehydrofuran $16 \mathbf{b}$ as a colorless oil: $R_{f} 0.57$ (40\% AcOEt in hexane); ${ }^{1} \mathrm{H}$ NMR (300 $\left.\mathrm{MHz} \mathrm{CDCl}_{3}\right): \delta 1.61(\mathrm{~s}, 6 \mathrm{H}), 3.83(\mathrm{~s}, 6 \mathrm{H}), 3.84(\mathrm{~s}, 3 \mathrm{H}), 3.88(\mathrm{~s}, 6 \mathrm{H}), 5.00(\mathrm{~s}, 2 \mathrm{H}), 5.69(\mathrm{~s}, 2 \mathrm{H})$, $6.53(\mathrm{~s}, 2 \mathrm{H}), 6.54(\mathrm{~s}, 2 \mathrm{H}), 7.32(\mathrm{~m}, 3 \mathrm{H})$, and $7.48(\mathrm{~m}, 2 \mathrm{H}) ;{ }^{13} \mathrm{C} \mathrm{NMR}\left(75 \mathrm{MHz}, \mathrm{CDCl}_{3}\right): \delta 10.5$, $56.1,56.2,60.8,75.0,91.7,104.0,104.1,127.8,128.1,128.5,130.9,131.1,136.7,137.1,137.2$, 137.7, 137.8, 153.4, and 153.7. ESI $[\mathrm{M}+1]^{+} 507$.

Phenol (17b). To a suspension of $\mathrm{Pd}(\mathrm{OH})_{2}$ on carbon $(20 \%, 3.6 \mathrm{mg})$ and 7,7'-dehydrofuran $\mathbf{1 6 b}$ (3.6 mg, $7.1 \mu \mathrm{mol})$ in 5\% AcOH in $\mathrm{MeOH}(1 \mathrm{~mL})$ was stirred for $24 \mathrm{~h}$ under $\mathrm{H}_{2}$ atmosphere at rt. The mixture was filtered through a pad of celite. The filtration was concentrated in vacuo, and then preparative silica gel TLC (40\% AcOEt in hexane) gave $1.5 \mathrm{mg}(51 \%)$ of phenol $\mathbf{1 7 b}$ as a colorless oil: $R_{f} 0.40$ (40\% AcOEt in hexane); ${ }^{1} \mathrm{H}$ NMR (300 MHz, $\left.\mathrm{CDCl}_{3}\right): \delta 1.60(\mathrm{~s}, 6 \mathrm{H}), 3.84$ $(\mathrm{s}, 3 \mathrm{H}), 3.88(\mathrm{~s}, 6 \mathrm{H}), 3.91(\mathrm{~s}, 6 \mathrm{H}), 5.51(\mathrm{~s}, 1 \mathrm{H}), 5.67(\mathrm{~s}, 2 \mathrm{H}), 6.53(\mathrm{~s}, 2 \mathrm{H})$, and $6.54(\mathrm{~s}, 2 \mathrm{H})$. ESI $[\mathrm{M}+1]^{+} 417$.

Phenols (19a and 19b). To a suspension of $\mathrm{Pd}(\mathrm{OH})_{2}$ on carbon $(20 \%, 4.0 \mathrm{mg})$ and carboxylic acids 12a and 12b $(12.0 \mathrm{mg}, 22.4 \mu \mathrm{mol})$ in $5 \% \mathrm{AcOH}$ in $\mathrm{MeOH}(1 \mathrm{~mL})$ was strring for $30 \mathrm{~min}$ under $\mathrm{H}_{2}$ atmosphere at $0{ }^{\circ} \mathrm{C}$. The mixture was filtered through a pad of celite. The filtration was concentrated in vacuo, and then preparative silica gel TLC $\left(5 \% \mathrm{EtOH}\right.$ in $\left.\mathrm{CH}_{2} \mathrm{Cl}_{2}\right)$ gave phenols 19a $\left(R_{f} 0.50,3.8 \mathrm{mg}, 38 \%\right)$ and $\mathbf{1 9 b}\left(R_{f} 0.52,5.7 \mathrm{mg}, 57 \%\right)$.

19 . Colorless solid, mp 122-124 ${ }^{\circ} \mathrm{C}(\mathrm{MeOH}) ;{ }^{1} \mathrm{H}$ NMR $\left(300 \mathrm{MHz}, \mathrm{CDCl}_{3}\right): \delta 2.07(\mathrm{dd}, 3 \mathrm{H}, J=$ 0.6, $2.1 \mathrm{~Hz}), 3.78$ (s, 6H), 3.81 (s, 3H), 3.85 (s, 6H), $5.61(\mathrm{dd}, 1 \mathrm{H}, J=0.6,4.2 \mathrm{~Hz}), 5.97$ (dd, 1H, $J=2.1,4.2 \mathrm{~Hz}), 6.51(\mathrm{~s}, 2 \mathrm{H})$, and $6.65(\mathrm{~s}, 2 \mathrm{H}) ;{ }^{13} \mathrm{C} \mathrm{NMR}\left(75 \mathrm{MHz}, \mathrm{CDCl}_{3}\right): \delta 13.1,56.1,56.3$, 
$60.8,87.5,91.7,104.8,104.9,126.6,131.9,134.6,135.0,138.2,147.0,153.5,155.5$ and 167.2. ESI [M-1] 445.

19b. Colorless solid, mp 123-125 ${ }^{\circ} \mathrm{C}(\mathrm{MeOH}) ;{ }^{1} \mathrm{H}-\mathrm{NMR}\left(300 \mathrm{MHz}, \mathrm{CDCl}_{3}\right): \delta 2.05$ (dd, $3 \mathrm{H}, J=$ $0.9,1.8 \mathrm{~Hz}), 3.85$ (s, 3H), 3.87 (s, 6H), 3.89 (s, 6H), $5.78(\mathrm{dd}, 1 \mathrm{H}, J=0.9,5.7 \mathrm{~Hz}), 6.11(\mathrm{dd}, 1 \mathrm{H}$, $J=1.8,5.7 \mathrm{~Hz}), 6.52(\mathrm{~s}, 2 \mathrm{H})$, and $6.60(\mathrm{~s}, 2 \mathrm{H}) ;{ }^{13} \mathrm{C}-\mathrm{NMR}\left(75 \mathrm{MHz}, \mathrm{CDCl}_{3}\right): \delta 12.9,56.2,56.3$, $60.8,88.3,92.0,104.1,104.3,126.9,131.8,134.8,135.0,138.4,147.1,153.6,155.3$ and 167.7. ESI [M-1] 445.

Phenol (20b). To a suspension of $\mathrm{Pd}(\mathrm{OH})_{2}$ on carbon $(20 \%, 3.6 \mathrm{mg})$ and allyl alcohol 14b $(10.0 \mathrm{mg}, 19.2 \mu \mathrm{mol})$ in $5 \% \mathrm{AcOH}$ in $\mathrm{MeOH}(1 \mathrm{~mL})$ was stirred for $30 \mathrm{~min}$ under a $\mathrm{H}_{2}$ atmosphere at $0{ }^{\circ} \mathrm{C}$. The mixture was filtered through a pad of celite. The filtrate was concentrated in vacuo, and then preparative silica gel TLC (100\% AcOEt) gave $7.0 \mathrm{mg}(84 \%)$ of phenol 20b as a colorless solid: $R_{f} 0.53(100 \% \mathrm{AcOEt}) ;{ }^{1} \mathrm{H}-\mathrm{NMR}\left(300 \mathrm{MHz}, \mathrm{CDCl}_{3}\right): \delta 1.61$ (bs, $1 \mathrm{H}), 1.68(\mathrm{~d}, 3 \mathrm{H}, J=0.9 \mathrm{~Hz}), 3.84(\mathrm{~s}, 3 \mathrm{H}), 3.88(\mathrm{~s}, 6 \mathrm{H}), 3.91(\mathrm{~s}, 6 \mathrm{H}), 4.02(\mathrm{~d}, 1 \mathrm{H}, J=12.6 \mathrm{~Hz})$, $4.32(\mathrm{~d}, 1 \mathrm{H}, J=12.6 \mathrm{~Hz}), 5.55(\mathrm{~s}, 1 \mathrm{H}), 5.72(\mathrm{~d}, 1 \mathrm{H}, J=5.4 \mathrm{~Hz}), 5.99$ (dd, $1 \mathrm{H}, J=0.9,5.4 \mathrm{~Hz})$, $6.75(\mathrm{~s}, 2 \mathrm{H})$, and $6.61(\mathrm{~s}, 2 \mathrm{H}) ;{ }^{13} \mathrm{C}-\mathrm{NMR}\left(75 \mathrm{MHz}, \mathrm{CDCl}_{3}\right): \delta 10.7,56.2,56.4,56.5,60.8,89.5$, 91.7, 103.7, 104.0, 132.3, 134.5, 134.7, 135.0, 136.7, and 137.9. ESI [M+1] 433 .

Arylidenemalonate (21). 3,4,6-Trimethoxybenzaldehyde (6, $1.00 \mathrm{~g}, 5.10 \mathrm{mmol}$ ) was converted to arylidenemalonate $\mathbf{2 1}(1.30 \mathrm{~g}, 75 \%)$ according to the procedure described above for $\mathbf{1 0}$ from $\mathbf{9}$. Yellowish oil; ESI $[\mathrm{M}+1]^{+} 353$.

Methylenetetrahydrofurans (22a and 22b). Arilidenemalonate 21 (338 mg, $1.00 \mathrm{mmol}$ ) was converted to methylenetetrahydrofurans $22 \mathbf{a}$ and $\mathbf{2 2 b}(1: 2,515 \mathrm{mg}, 92 \%)$ according to the procedure described above for $\mathbf{1 1}$ from $\mathbf{1 0}$.

22a. Gummy; $R_{f} 0.52$ (40\% AcOEt in hexane); ${ }^{1} \mathrm{H}-\mathrm{NMR}\left(300 \mathrm{MHz}, \mathrm{CDCl}_{3}\right): \delta 0.84$ (t, $3 \mathrm{H}, J=$ $6.9 \mathrm{~Hz}), 1.31(\mathrm{t}, 3 \mathrm{H}, J=6.9 \mathrm{~Hz}), 3.51(\mathrm{~m}, 1 \mathrm{H}), 3.80(\mathrm{~m}, 1 \mathrm{H}), 3.82(\mathrm{~s}, 3 \mathrm{H}), 3.85(\mathrm{~s}, 6 \mathrm{H}), 3.88(\mathrm{~s}$, $3 \mathrm{H}), 3.91(\mathrm{~s}, 6 \mathrm{H}), 4.32(\mathrm{~m}, 2 \mathrm{H}), 5.03(\mathrm{~d}, 1 \mathrm{H}, J=2.7 \mathrm{~Hz}), 5.30(\mathrm{~d}, 1 \mathrm{H}, J=2.7 \mathrm{~Hz}), 5.62(\mathrm{t}, 1 \mathrm{H}, J$ $=2.7 \mathrm{~Hz}), 5.76(\mathrm{~s}, 1 \mathrm{H}), 6.80(\mathrm{~s}, 2 \mathrm{H}), 6.93(\mathrm{~s}, 2 \mathrm{H}) ;{ }^{13} \mathrm{C}-\mathrm{NMR}\left(75 \mathrm{MHz}, \mathrm{CDCl}_{3}\right): \delta 13.5,13.9$, 55.1, 55.9, 56.0, 61.4, 61.9, 68.9, 83.6, 83.9, 103.9, 106.0, 132.5, 135.1, 137.7, 149.3, 152.7, 153.1, 168.1, 168.3. ESI [M+1] 561 .

22b. Gummy; $R_{f} 0.51$ (40\% AcOEt in hexane); ${ }^{1} \mathrm{H}-\mathrm{NMR}\left(300 \mathrm{MHz}, \mathrm{CDCl}_{3}\right): \delta 0.86(\mathrm{t}, 3 \mathrm{H}, J=$ $6.3 \mathrm{~Hz}), 1.30(\mathrm{t}, 3 \mathrm{H}, J=6.3 \mathrm{~Hz}), 3.54(\mathrm{~m}, 1 \mathrm{H}), 3.82(\mathrm{~s}, 3 \mathrm{H}), 3.85(\mathrm{~m}, 9 \mathrm{H}), 3.87(\mathrm{~s}, 6 \mathrm{H}), 3.88(\mathrm{~s}$, $1 \mathrm{H}), 4.32(\mathrm{~m}, 2 \mathrm{H}), 5.26(\mathrm{~d}, 1 \mathrm{H}, J=2.1 \mathrm{~Hz}), 5.70(\mathrm{~d}, 1 \mathrm{H}, J=2.1 \mathrm{~Hz}), 5.86(\mathrm{t}, 1 \mathrm{H}, J=2.1 \mathrm{~Hz})$, $5.91(\mathrm{~s}, 1 \mathrm{H}), 6.62(\mathrm{~s}, 2 \mathrm{H}), 6.74(\mathrm{~s}, 2 \mathrm{H}) ;{ }^{13} \mathrm{C}-\mathrm{NMR}\left(75 \mathrm{MHz}, \mathrm{CDCl}_{3}\right): \delta$ 13.4, 14.0, 55.0, 60.7, $60.8,61.6,61.2,69.0,83.7,83.8,103.9,104.4,113.7,133.7,136.1,137.8,147.7,152.8,153.2$, 167.6, 167.8. ESI $[\mathrm{M}+1]^{+} 561$.

Carboxylic acids (23a and 23b). methylenetetrahydrofurans 22a and 22b (100 mg, $0.18 \mathrm{mmol})$ was converted to carboxylic acids $23 \mathbf{a}$ and $\mathbf{2 3 b}$ (72 $\mathrm{mg}, 89 \%$ ) according to the procedure described above for 12 from 11.

23a. Colorless solid, Mp $134-137^{\circ} \mathrm{C}(\mathrm{MeOH}) ; R_{f} 0.55-0.40$ (70\% AcOEt in hexane), $R_{f} 0.48(5 \%$ $\mathrm{MeOH}$ in $\left.\mathrm{CH}_{2} \mathrm{Cl}_{2}\right) ;{ }^{1} \mathrm{H}-\mathrm{NMR}\left(300 \mathrm{MHz}, \mathrm{CDCl}_{3}\right)$ : $\delta 2.08(\mathrm{bs}, 3 \mathrm{H}), 3.77(\mathrm{~s}, 6 \mathrm{H}), 3.84(\mathrm{~s}, 6 \mathrm{H}), 3.85$ $(\mathrm{s}, 6 \mathrm{H}), 5.62(\mathrm{~d}, 1 \mathrm{H}, J=4.2 \mathrm{~Hz}), 5.98(\mathrm{dd}, 1 \mathrm{H}, J=2.1,4.2 \mathrm{~Hz}), 6.50(\mathrm{~s}, 2 \mathrm{H}), 6.65(\mathrm{~s}, 2 \mathrm{H})$. ESI 
$[\mathrm{M}+1]^{+} 459$.

23b. Colorless solid, $\mathrm{Mp} 134-138^{\circ} \mathrm{C}(\mathrm{MeOH}) ; R_{f} 0.67-0.55$ (70\% AcOEt in hexane), $R_{f} 0.49$ (5\% $\mathrm{MeOH}$ in $\left.\mathrm{CH}_{2} \mathrm{Cl}_{2}\right) ;{ }^{1} \mathrm{H}-\mathrm{NMR}\left(300 \mathrm{MHz}, \mathrm{CDCl}_{3}\right)$ : $\delta 2.06$ (bs, 3H), $3.81(\mathrm{~s}, 3 \mathrm{H}), 3.82(\mathrm{~s}, 3 \mathrm{H}), 3.87$ (s, 6H), 3.89 (s, 6H), 5.79 (d, 1H, J=5.4 Hz), $6.13(\mathrm{dd}, 1 \mathrm{H}, J=1.5,5.4 \mathrm{~Hz}), 6.52(\mathrm{~s}, 2 \mathrm{H}), 6.61$ $(\mathrm{s}, 2 \mathrm{H})$. ESI $[\mathrm{M}+1]^{+} 459$.

Esters (24a and 24b). Carboxylic acid 23a and 23b (60 $\mathrm{mg}, 0.13 \mathrm{mmol})$ was converted to ethers 24a and 24b (61 mg, quant.) according to the procedure described above for $\mathbf{1 3}$ from $\mathbf{1 2}$.

24a. Colorless oil; $R_{f} 0.44$ (40\% AcOEt in hexane); ${ }^{1} \mathrm{H}-\mathrm{NMR}\left(300 \mathrm{MHz}, \mathrm{CDCl}_{3}\right): \delta 2.05$ (bs, $3 \mathrm{H}), 3.69(\mathrm{~s}, 3 \mathrm{H}), 3.77(\mathrm{~s}, 6 \mathrm{H}), 3.84(\mathrm{~s}, 6 \mathrm{H}), 3.85(\mathrm{~s}, 3 \mathrm{H}), 5.61(\mathrm{~d}, 1 \mathrm{H}, J=4.8 \mathrm{~Hz}), 5.97(\mathrm{dd}, 1 \mathrm{H}$, $J=2.1,4.8 \mathrm{~Hz}), 6.50(\mathrm{~s}, 2 \mathrm{H}), 6.63(\mathrm{~s}, 2 \mathrm{H})$. ESI [M+1] ${ }^{+} 475$.

24b. Colorless oil; $R_{f} 0.46$ (40\% AcOEt in hexane); ${ }^{1} \mathrm{H}-\mathrm{NMR}\left(300 \mathrm{MHz}, \mathrm{CDCl}_{3}\right): \delta 2.03$ (bs, $3 \mathrm{H}), 3.71(\mathrm{~s}, 3 \mathrm{H}), 3.81(\mathrm{~s}, 3 \mathrm{H}), 3.82(\mathrm{~s}, 3 \mathrm{H}), 3.87(\mathrm{~s}, 6 \mathrm{H}), 3.88(\mathrm{~s}, 6 \mathrm{H}), 5.79(\mathrm{dd}, 1 \mathrm{H}, J=0.9,5.1$ $\mathrm{Hz}), 6.14(\mathrm{dd}, 1 \mathrm{H}, J=1.8,5.1 \mathrm{~Hz}), 6.53(\mathrm{~s}, 2 \mathrm{H}), 6.60(\mathrm{~s}, 2 \mathrm{H})$. ESI $[\mathrm{M}+1]^{+} 475$.

Allyl alcohol (25a and 25b). Ethers 24a and 24b (30 mg, $0.06 \mathrm{mmol}$ ) was converted to ethers 25a (6.0 mg, 20\%) and 25b (13 mg, 50\%) according to the procedure above described for 14 from 13.

25a. Colorless oil; $R_{f} 0.37$ (60\% AcOEt in hexane); ${ }^{1} \mathrm{H}-\mathrm{NMR}\left(300 \mathrm{MHz}, \mathrm{CDCl}_{3}\right): \delta 1.70$ (bs, $3 \mathrm{H}), 3.81(\mathrm{~s}, 6 \mathrm{H}), 3.83(\mathrm{~s}, 6 \mathrm{H}), 3.85(\mathrm{~s}, 6 \mathrm{H}), 4.12(\mathrm{~d}, 1 \mathrm{H}, J=16.8 \mathrm{~Hz}), 4.35(\mathrm{~d}, 1 \mathrm{H}, J=16.8 \mathrm{~Hz})$, $5.55(\mathrm{~d}, 1 \mathrm{H}, J=3.9 \mathrm{~Hz}), 5.83(\mathrm{~m}, 1 \mathrm{H}), 6.57(\mathrm{~s}, 2 \mathrm{H}), 6.65(\mathrm{~s}, 2 \mathrm{H})$. ESI [M+1] 447.

25b. Colorless oil; $R_{f} 0.46\left(60 \%\right.$ AcOEt in hexane); ${ }^{1} \mathrm{H}-\mathrm{NMR}\left(300 \mathrm{MHz}, \mathrm{CDCl}_{3}\right): \delta 1.67(\mathrm{bs}$, $3 \mathrm{H}), 3.82(\mathrm{~s}, 6 \mathrm{H}), 3.87(\mathrm{~s}, 6 \mathrm{H}), 3.88(\mathrm{~s}, 6 \mathrm{H}), 4.02(\mathrm{~d}, 1 \mathrm{H}, J=17.1 \mathrm{~Hz}), 4.34(\mathrm{~d}, 1 \mathrm{H}, J=17.1 \mathrm{~Hz})$, $5.74(\mathrm{~d}, 1 \mathrm{H}, \mathrm{J}=5.7 \mathrm{~Hz}), 6.02(\mathrm{~d}, 1 \mathrm{H}, J=5.7 \mathrm{~Hz}), 6.58(\mathrm{~s}, 2 \mathrm{H}), 6.62(\mathrm{~s}, 2 \mathrm{H})$. ESI [M+1] 447.

In vitro bioassay: the bioassays were carried out using blood collected by cardiac puncture of Swiss albino mice in the parasitemy peak ( $7^{\text {th }}$ day) after infection with the Y strain of T. cruzi. The infected blood was diluted with blood of healthy mice to achieve a concentration of $10^{6}$ trypomastigote forms $/ \mathrm{mL}$. The standard solutions (in DMSO) were added into the infected blood to provide concentrations of 5.0, 25.0 and $50.0 \mu \mathrm{g} / \mathrm{mL}$, respectively. The plates were incubated at $4^{\circ} \mathrm{C}$ during 24 hours and the number of parasites determined according to method described ${ }^{5}$. The bioassays were performed in triplicate on microtiter plates (96 wells), which contained 200 $\mu \mathrm{L}$ of mixture/well. Negative and positive controls containing either DMSO or gentian violet were carried out in parallel.

\section{Acknowledgements}

This work was funded by grants provided by FAPESP, BASA and CNPq/PADCT. 


\section{References}

1. WHO data obtained from http:/www.who.ch

2. Taube, G. Science 2000, 290, 434.

3. Filho, A. A. F.; Luquetti, A. O.; Prata, A.; Rassi, A.; Gontijo, E. D.; Ferreira, H. de O.; Cançardo, J. R.; Coura, J. R.; Andrade, S. G.; Macedo, V.; Neto, V. A.; de Oliveira, Jr, W.; Brener, Z. Parasitol. Today 1997, 13, 127.

4. Docampo, R.; Schmuñis, C. A. Parasitol. Today 1997, 13, 127.

5. Brener, Z. Annu. Rev. Microbiol. 1973, 27, 347.

6. Urbina, J. A.; Payares, G.; Molina, J.; Sanoja, C.; Liendo, A.; Lazardi, K.; Piras, M.; Piras, R.; Perez, N.; Wincker, P.; Ryley, J. F. Science 1996, 273, 969.

7. Cerecetto, H.; Di Maio, R.; González, M.; Risso, M.; Saenz, P.; Seoane, G.; Denicola, A.; Peluffo, G.; Quijano, C.; Olea-Azar, C. J. Med. Chem. 1999, 42, 1941.

8. Schirmer, R. H.; Müller, J. G.; Krauth-Siegel, R. L. Angew. Chem., Int. Ed. 1995, 34, 141.

9. Di Pentima, M. C.; Hwang, L. Y.; Skeeter, M. C.; Edwards, M. S. Clin. Infect. Dis. 1999, 28, 1281.

10. Docampo, R.; Moreno, S. N. J. Rev. Biochem. Toxicol. 1985, 7, 159.

11. Vieira, H. H.; Takahashi, J. A., Oliveira, A. B.; Chiari, E.; Boaventura, M. A. J. Braz. Chem. Soc. 2002, 13, 151.

12. De Moura, K. C. G.; Emery, F. S.; Neves-Pinto, C.; Pinto, M. C. R. R.; Dantas, A. P.; Salomão, K., Castro, S. L.; Pinto, A. V. J. Braz. Chem. Soc. 2001, 12, 325.

13. Lopes, N. P.; Chicaro, P.; Kato, M. J.; Albuquerque, S.; Yoshida, M. Planta. Med. 1998, 64, 667.

14. Abe, F.; Nagafuji, S.; Yamauchi, T.; Okabe, H.; Maki, J.; Higo, H.; Akahane, H.; Aguilar, A.; Jimenez-Estrada, M.; Reyes-Chilpa, R. Biol. Pharm. Bull. 2002, 25, 1188.

15. da Silva Filho, A. A.; Albuquerque, S.; Silva, M. L. A; Eberlin, M. N.; Tomazela, D. M.; Bastos, J. K. J. Nat. Prod. 2004, 67, 42.

16. Marat, X.; Monteiro, N.; Balme, G. Synlett 1997, 845.

17. Swenton, J. S.; Raynolds, P. W. J. Am. Chem. Soc. 1978, 100, 6188.

18. Allen, F. H.; Spangler, F. W. Organic Syntheses; Wiley: New York, 1955; Collect. Vol. III, p 337

19. Krapcho, A. P. Synthesis 1982, 805.

20. Toyota, M.; Odashima, T.; Wada, T.; Ihara, M. J. Am. Chem. Soc. 2000, 122, 9036.

21. Silva, L. H. O.; Nussenzweig, V. Fol. Clin. Biol. 1953, 20, 191.

22. Bottex, M.; Cavicchioli, M.; Hartmann, B.; Monteiro, N.; Balme, G. J. Org. Chem. 2001, 66, 175.

23. Bennett, C. J.; Caldwell, S. T.; McPhail, D. B.; Morrice, P. C.; Duthieb, G. G.; Hartleya, R. C. Bioorg. Med. Chem. 2004, 12, 2079. 